\title{
Impact of Lactic Acid on Formation of Biogenic Amines in Common Carp
}

\author{
Seyyed Mohammad Ali Noori \\ (MSc) \\ 2. PhD Student, Department of \\ Food Hygiene and Aquaculture, \\ Faculty of Veterinary Medicine, \\ Ferdowsi University of Mashhad, \\ Mashhad, Iran
}

\section{Ali Fazlara(PhD)}

Department of Food Hygiene, Faculty of Veterinary Medicine, Shahid Chamran University of Ahvaz, Ahvaz, Iran

Hossein Najafzadehvarzi(PhD) Department of Pharmacology, Faculty of Veterinary Medicine, Shahid Chamran University of Ahvaz, Ahvaz, Iran

Mohammad Azizzadeh(PhD) Department of Clinical Sciences, Faculty of Veterinary Medicine, Ferdowsi University of Mashhad, Mashhad, Iran

\section{Saeid Khanzadi(PhD)}

Department of Food Hygiene and Aquaculture, Faculty of Veterinary Medicine, Ferdowsi University of Mashhad, Mashhad, Iran

Corresponding Author: Saeid khanzadi

Tel: +989163026787

Email: khanzadi@um.ac.ir

Address: Ferdowsi University of Mashhad, Mashhad, Iran

Received : 14 Jul 2015

Revised: 15 Nov 2015

Accepted: 10 Nov 2015

\begin{abstract}
Background and Objective: Raw fish is a highly perishable product that deteriorates due to chemical changes and microbial growth. Biogenic amines (BAs) are generated in course of bacterial spoilage in fish that may lead to BA toxicity, particularly in adverse storage conditions. The purpose of this study was to prevent the BAs toxicity caused by common carp (Cyprinus carpio).

Methods: Live Common carps were purchased from a local market. The samples were first divided into control and lactic acid treatment groups, and then stored at $4 \mathrm{C}$. the concentrations of three BAs were determined (histamine, putrescine and cadaverine) with high performance liquid chromatography equipped with IV detector.

Results: Cadaverine and putrescine had the highest concentrations in control group (400.42 and $293.90 \mathrm{mg} / \mathrm{kg}$, respectively). Histamine remained undetectable until the middle of storage period. Histamine and cadaverine concentrations in the lactic acid group were significantly lower compared to that of control group $(\mathrm{p}<0.05)$.

Conclusion: The formation of histamine and cadaverine is effectively controlled by lactic acid treatment, although such effect was not observed on putrescine in the entire storage period.

Keywords: Biogenic Amines, Toxicity, Carps, Histamine.
\end{abstract}




\section{INTRODUCTION}

Common carp (Cyprinus carpio) is an economically important fish species that is mostly cultured in Asia, Europe, Australia and South America. It is favored for its fast growth rate, easy cultivation and high feed efficiency (1). Raw fish is a highly perishable product that deteriorates due to chemical changes and microbial growth. These changes affect fish proteins resulting in formation of peptides and amino acids, which can be further converted to biogenic amines (BAs) under the decarboxylase activity of naturally present microorganisms (2).

Generally, low concentrations of BAs in food and beverages (practically under $100 \mathrm{mg} / \mathrm{kg}$ ) do not pose a significant risk for human health. Human intestinal tract has a detoxifying system consisting of monoaminooxidase, diaminooxidase, and histamine methyltranspherase. However, higher amounts of BAs (generally above $100 \mathrm{mg} / \mathrm{kg}$ ) may induce undesirable psychoactive and vasoactive effects including hypotension or hypertension, headache, nausea and breathing problems. Histamine (HIS) may cause the latter mentioned undesirable effects directly. Since putrescine (PUT) and cadaverine (CAD) can inhibit the detoxifying enzymatic system, they can act as potentiators of HIS's effects (2-5).

Fish and fish products are consumed insufficiently in Iran, which could lead to BA toxicity. Thus, it is essential to seek new ways to prevent the formation of BAs in fish. Organic acids are generally recognized as safe additives, but may produce adverse sensory changes. However, the dilute solutions of organic acids $(1-3 \%)$ are generally without effect on the desirable sensory properties (6). The bactericidal effect of organic acids (e.g. lactic acid) is due to metabolic inhibition and reduction of $\mathrm{pH}$ below the optimal range for microbial growth. Therefore, it could be useful for prevention of BAs formation and inhibition of BAs toxicity.

The aim of this study was to evaluate the effects of lactic acid (as a food additive) treatment on the formation of three BAs (HIS, PUT and CAD).

\section{MATERIAL AND METHODS}

Live common carps with mean weight of $1 \pm 0.1 \mathrm{~kg}$ were purchased from a local seafood market in the vicinity of Ahvaz, Khuzestan Province. The fishes were stunned, decapitated, gutted and filleted (120 g average weight/slice) using market facilities. The fillets were then transported to laboratory in polystyrene boxes filled with ice. The fish fillets were washed carefully with cold water, and divided into two groups. The first group was left untreated (control group) while the second group was treated with $1.5 \%$ lactic acid solution (Merck, Germany) for $30 \mathrm{~min}$. The samples were packed in polyethylene containers and stored in refrigerator at $4 \mathrm{C}$ for 18 days until analysis. The samples were analyzed after $0,3,6,9,12,15$, and 18 days of storage (3 samples per day).

Evaluation of BA formation was carried out according to the procedure previously described by Dawood et al. (7). Briefly, $10 \mathrm{~g}$ of each sample were homogenized with $75 \mathrm{ml}$ of trichloroacetic acid (TCA, $5 \mathrm{~g} / 100 \mathrm{ml}$ ) in a blender for $2 \mathrm{~min}$. After centrifugation at 2000 $\mathrm{g}$ for $10 \mathrm{~min}$, the supernatant was filtered through Whatman filter No. 1 . The filtrate was made up to $100 \mathrm{ml}$ with 5\% TCA. Two $\mathrm{ml}$ of the solution were transferred to glass tubes $(25$ $\mathrm{ml}$ capacity); ; one $\mathrm{ml}$ of $\mathrm{NaOH}$ ( $2 \mathrm{~N}$, Merck, Germany) and $10 \mu \mathrm{l}$ benzoyl chloride (Merck, Germany) were added to the tubes and the tubes were immersed in $30{ }^{\circ} \mathrm{C}$ water. After adding $2 \mathrm{ml}$ of saturated $\mathrm{NaCl}$ and $3 \mathrm{ml}$ diethyl ether, the tubes were centrifuged at $3000 \mathrm{~g}$ for $10 \mathrm{~min}$. Organic supernatant was transferred into another glass tube and placed in oven at $70 \mathrm{C}$. The extracts were evaporated to dryness in a current of air. The residue was dissolved in $200 \mu \mathrm{l}$ of methanol (HPLC grade) and filtered through millipore filter $(0.45 \mu \mathrm{m}$ pore size). Then, $20 \mu \mathrm{l}$ aliquots were injected for HPLC analysis. Quantification of BAs was carried out using an HPLC system with UVvis detection (Shimadzu, Japan). The mobile phase was an isocratic mixture of methanol: water (70: 30 by volume), with flow rate of 1 $\mathrm{ml} / \mathrm{min}$ at room temperature. The peaks were detected at $254 \mathrm{~nm}$.

The data was analyzed using SPSS 21 and repeated measure ANOVA. P-values < 0.05 were considered as statistically significant.

\section{RESULTS}

Table 1 show the formation of BAs in common carp in the two groups. The highest concentration of BAs was related to CAD in the control group ( $400.42 \mathrm{mg} / \mathrm{kg}$ ). 
Table 1- Changes in concentrations of BAs in common carp (mg/kg muscle)

\begin{tabular}{|c|c|c|c|c|c|c|c|c|}
\hline \multirow[t]{2}{*}{ BAs } & \multirow[t]{2}{*}{ Groups } & \multicolumn{7}{|c|}{ Days } \\
\hline & & $\mathbf{0}$ & 3 & 6 & 9 & 12 & 15 & 18 \\
\hline \multirow{2}{*}{$\underset{(\mathbf{m g} / \mathbf{k g})}{\text { HIM }}$} & Control $^{\mathrm{a}}$ & ND & ND & 0.49 & 0.14 & ND & 0.35 & 2.99 \\
\hline & Lactic acid $^{\mathrm{b}}$ & ND & ND & ND & 0.05 & ND & 0.040 & 0.82 \\
\hline \multirow{2}{*}{$\underset{(\mathrm{mg} / \mathrm{kg})}{\mathrm{CAD}}$} & Control $^{\mathrm{a}}$ & 64.03 & 48.04 & 101.58 & 76.49 & 127.26 & 400.42 & 307.73 \\
\hline & Lactic acid $^{\mathbf{b}}$ & ND & ND & ND & ND & ND & ND & ND \\
\hline \multirow{2}{*}{$\begin{array}{c}\text { PUT } \\
(\mathbf{m g} / \mathbf{k g})\end{array}$} & Control $^{\mathrm{a}}$ & 21.93 & ND & 16.32 & 23.81 & 26.98 & 39.52 & 84.21 \\
\hline & Lactic acid $^{b}$ & 13.65 & ND & 34.76 & 149.91 & 100.34 & 293.90 & 23.33 \\
\hline
\end{tabular}

The control and lactic acid treatment groups were stored at $4{ }^{\circ} \mathrm{C}$ for 18 days.

${ }^{\mathrm{ab}}$ for each BA, different superscript letters show significant difference between groups during the study period $(\mathrm{P}<0.05)$.

HIM was undetectable until day 9. Final concentration of HIM at the end of storage period was 2.99 and $0.82 \mathrm{mg} / \mathrm{kg}$ in the control and lactic acid groups, respectively.

CAD was not detected in the lactic acid group on the first day of storage, while concentration of $64.03 \mathrm{mg} / \mathrm{kg}$ was found in the control group. CAD concentration increased to 307.73 $\mathrm{mg} / \mathrm{kg}$ at the end of storage period in the control group and remained undetectable in the lactic acid group. In this study, the amount of PUT in the control group was ranging between 21.93 and $84.21 \mathrm{mg} / \mathrm{kg}$. The concentration of PUT in the treatment group was $13.65 \mathrm{mg} / \mathrm{kg}$ on the first day (day 0), but later increased to $293.90 \mathrm{mg} / \mathrm{kg}$ on day 15 . However, the CAD concentration decreased by $23.33 \mathrm{mg} / \mathrm{kg}$ on the last day of storage.

\section{DISCUSSION}

PUT, CAD and HIS can act as indicators of spoilage in fish. HIS is the causative agent for fish poisoning, while PUT and CAD potentiate the toxicity of histamine (8). Results of this study showed low total BAs concentrations at day 0 of storage, which is similar to results obtained by Restuccia et al. (9), Hu et al. (10) and Wang et al. (11).

The highest concentration of HIM was observed in the control group. this concentration in the treatment group was significantly lower than that in the control group $(\mathrm{P}<0.05)$. Lactic acid treatment inhibits the growth of bacteria with histidine decarboxylase activity. HIS is the main BA involved in human food poisoning that can be a major threat to public health. According to the results of this study, application of lactic acid could be useful in prevention of histamine toxicity and food-borne poisoning.

The CAD content in the control group was significantly higher than that in the lactic acid treatment group $(p<0.05)$. Moreover, CAD concentration in the treatment group remained below the limit of detection. It was demonstrated that lactic acid can significantly reduce the formation of CAD in carp roe (12).

Although CAD was not detected in the lactic acid group, PUT was found in all samples (except on day 3) because it is a substance present in all living cells. The level of PUT generally exceeds $15 \mathrm{mg} / \mathrm{kg}$ in low quality samples (12). In this study, the PUT level in the control group was higher than the mentioned limit in the entire study, while PUT concentration in the lactic acid group remained below $15 \mathrm{mg} / \mathrm{kg}$ for only three days. However, the PUT content was much higher in the lactic acid group on days 6, 9, 12 and 15. Min et al. reported that HIM, PUT and CAD concentrations reduce in beef inoculated with Enterobacter cloacae after one day of treatment with lactic acid (13). Sirocchi et al. (14) investigated the effect of essential oils on BAs formation in meat stored at $4{ }^{\circ} \mathrm{C}$. They found that the essential oils have potential inhibitory effects on HIS, PUT and CAD accumulation, which increases the shelf life of fresh meat and preserves its important 
nutrients. In the present study, PUT and CAD concentrations were higher than HIM concentrations in common carp muscle. Krizek et al. found that PUT and CAD are dominant BAs in carp flesh $(15,16)$.

BA formation is temperature-dependent (17), and declines at low temperatures (18) through inhibition of microbial growth and reduction of enzyme activity $(19,20)$. There is a higher chance of BA formation in South of Iran due to the hot climate and adverse storage conditions, which could pose a major threat to human health.

\section{CONCLUSION}

Lactic acid treatment of common carp at 4

\section{REFERENCES}

1. Irawan $\mathrm{H}, \mathrm{Vuthiphandchai} \mathrm{V}$, Nimrat $\mathrm{S}$. The effect of extenders, cryoprotectants and cryopreservation methods on common carp (Cyprinus carpio) sperm. Animal reproduction science. 2010; 122(3): 236-43. doi: 10.1016/j.anireprosci.2010.08.017.

2. Halász A, Baráth Á, Simon-Sarkadi L, Holzapfel W. Biogenic amines and their production by microorganisms in food. Trends in Food Science \& Technology. 1994; 5(2): 42-9.

3. Arnold $\mathrm{H}$, Brown D. Histamine toxicity from fish products. Adv Food Res. 1978; 24: 113-54.

4. Buňková L, Buňka $F$, Hlobilová $M$, Vaňátková $Z$, Nováková D, Dráb V. Tyramine production of technological important strains of Lactobacillus, Lactococcus and Streptococcus. European Food Research and Technology. 2009; 229(3): 533-8.

5. Ten Brink B, Damink C, Joosten H, In't Veld JH. Occurrence and formation of biologically active amines in foods. International journal of food microbiology. 1990; 11(1): 73-84.

6. Smulders F, Greer G. Integrating microbial decontamination with organic acids in HACCP programmes for muscle foods: prospects and controversies. International Journal of Food Microbiology. 1998; 44(3): 149-69.

7. Dawood AA, Karkalas J, Roy RN, Williams CS. The occurrence of non-volatile amines in chilled-stored rainbow trout (Salmo irideus). Food Chemistry. 1988; 27(1): 33-45.

8. Cai L, Cao A, Li Y, Song Z, Leng L, Li J. The effects of essential oil treatment on the biogenic amines inhibition and quality preservation of red drum (Sciaenops ocellatus) fillets. Food Control. 2015; 56: 1-8.

9. Restuccia D, Spizzirri UG, Bonesi M, Tundis R, Menichini F, Picci N, et al. Evaluation of fatty acids and biogenic amines profiles in mullet and tuna roe during
${ }^{\circ} \mathrm{C}$ prolongs its shelf life up to 3-5 days and reduces HIM and CAD formation. The results also showed that lactic acid only affects PUT content until day three. It is suggested to use lactic acid along with other preservatives such as essential oils to reduce BA concentrations more efficiently.

\section{ACKNOWLEDGMENT}

This study has been supported by Ferdowsi University of Mashhad and Shahid Chamran University of Ahvaz.

\section{CONFLICT OF INTEREST}

The authors declare no conflicts of interest regarding this manuscript.

six months of storage at 4 C. Journal of Food Composition and Analysis. 2015; 40: 52-60.

10. $\mathrm{Hu} \mathrm{Y}$, Huang Z, Li J, Yang H. Concentrations of biogenic amines in fish, squid and octopus and their changes during storage. Food chemistry. 2012;135(4): 2604-11. doi: 10.1016/j.foodchem.

11. Wang $\mathrm{H}$, Luo $\mathrm{Y}$, Huang $\mathrm{H}, \mathrm{Xu}$ Q. Microbial succession of grass carp (Ctenopharyngodon idellus) filets during storage at $4^{\circ} C$ and its contribution to biogenic amines' formation. International journal of food microbiology. 2014; 190: 66-71.

12. Kř́žek M, Vácha F, Pelikánová T. Biogenic amines in carp roe (Cyprinus carpio) preserved by four different methods. Food Chemistry. 2011;126(3):1493-7.

13. Min J-S, Lee S-O, Jang A, Jo C, Lee M. Irradiation and organic acid treatment for microbial control and the production of biogenic amines in beef and pork. Food chemistry. 2007; 104(2): 791-9.

14. Sirocchi V, Caprioli G, Cecchini C, Coman MM, Cresci A, Maggi F, et al. Biogenic amines as freshness index of meat wrapped in a new active packaging system formulated with essential oils of Rosmarinus officinalis. International journal of food sciences and nutrition. 2013; 64(8): 921-8.

15. Kř́ižek M, Pavlíček T, Vácha F. Formation of selected biogenic amines in carp meat. Journal of the Science of Food and Agriculture. 2002; 82(9):1088-93. DOI: $10.1002 /$ jsfa. 1154 .

16. Křížek $\mathrm{M}$, Vácha $\mathrm{F}$, Vorlová L, Lukášová J, Cupáková Š. Biogenic amines in vacuum-packed and non-vacuum-packed flesh of carp (Cyprinus carpio) stored at different temperatures. Food Chemistry. 2004; 88(2): 185-91.

17. Shalaby AR. Significance of biogenic amines to food safety and human health. Food Research International. 1996;29(7):675-90. doi:10.1016/S0963-9969(96)00066-

$\mathrm{X}$. 
18. Prester L, Macan J, Varnai VM, Orct T, Vukušić J, Kipčić D. Endotoxin and biogenic amine levels in Atlantic mackerel (Scomber scombrus), sardine (Sardina pilchardus) and Mediterranean hake (Merluccius merluccius) stored at 22 C. Food Additives and Contaminants. 2009; 26(3): 355-62.

19. Du WX, Lin CM, Phu AT, Cornell J, Marshall M, Wei CI. Development of Biogenic Amines in Yellowfin
Tuna (Thunnus albacares): Effect of Storage and Correlation with Decarboxylase-Positive Bacterial Flora. Journal of food science. 2002; 67(1): 292-301. DOI: $10.1111 / \mathrm{j} .1365-2621.2002 . t b 11400 . x$.

20. Mah J-H, Hwang H-J. Inhibition of biogenic amine formation in a salted and fermented anchovy by Staphylococcus xylosus as a protective culture. Food Control. 2009; 20(9): 796-801. 